\title{
The Impact of Banking Finance on Financial Performance of Egyptian Small Businesses in Period from 2013 to 2016
}

\author{
Eslam Mahmoud Saadallah, Ashraf Salah \\ The Arab Academy for Science and Technology \& Maritime Transport, Alexandria, Egypt \\ Email: eslamsaadallah@gmail.com
}

How to cite this paper: Saadallah, E.M. and Salah, A. (2019) The Impact of Banking Finance on Financial Performance of Egyptian Small Businesses in Period from 2013 to 2016. Open Access Library Journal, 6: e5146.

https://doi.org/10.4236/oalib.1105146

Received: December 26, 2018

Accepted: August 24, 2019

Published: August 27, 2019

Copyright $\odot 2019$ by author(s) and Open Access Library Inc.

This work is licensed under the Creative Commons Attribution International License (CC BY 4.0).

http://creativecommons.org/licenses/by/4.0/

(c) (i) Open Access

\begin{abstract}
Small business becomes important for the economic development as it acts as an engine of employment. This research focuses on the impact of banking finance at a normal interest rate on small business financial performance. The research approach adopted in this dissertation includes quantitative secondary data from annual reports of 90 small business firms in Egypt in period from 2013 to 2016 (2013 and 2014 without loan, 2015 and 2016 with a loan). Data was collected for the research variables; Loan Volume, Return on Assets, Return on Equity and Net Profit Margin. Loans Volume at a normal interest rate represents the independent variable, Firm Leverage and firm age represent the control variable, and Financial Performance Indicators (ROE, ROA and NPM) represent the dependent variable. Results showed that loan volume has a negative significant impact to financial performance of small business, firm leverage has a negative significant impact to financial performance of small business and firm age has insignificant impact to financial performance of small business.
\end{abstract}

\section{Subject Areas}

Economics

\section{Keywords}

Banking Finance, Loan Volume, Financial Performance, Return on Assets, Return on Equity, Net Profit Margins

\section{Introduction}

The economy in Egypt, socially, entrepreneurship empowers citizens, generates 
innovation and changes mindsets, economically, entrepreneurship stimulates markets. Thus, entrepreneurship is described as a potential driver to support the economic growth, but the ability of small business access to finance has always been considered a major obstacle facing many small businesses [1]. Small Businesses in Egypt provide almost 60 percent of jobs and three quarters of the national value added but access to external finance is an important barrier to small entrepreneurs development in Egypt similarly to many other countries so small business needs to provide a business environment in terms of regulations and the way they are implemented and the government needs to improve infrastructure and access to markets to open opportunities for small entrepreneurs [2]. Supporting of small business is a complex phenomenon. Although it has gained academic interest, there is no single model that has been developed to date that can adequately explain why some small business grows and others do not. On 6/12/2015, the Central Bank of Egypt made a decision (the initiative of the Central Bank of Egypt to support the small business) which includes the following:

- Increasing the portfolio of loans and facilities granted to small and medium enterprises to not less than $20 \%$ of the total portfolio of the bank within 4 years from the date of issuing these instructions.

- Targeting 200 billion pounds to finance small projects within 4 years.

- The lending rate for small and very small businesses does not exceed 5\% (decline simple rate).

- Care of small industrial companies, small labor-intensive companies, small business that have innovative ideas and small companies that target export.

- New credit facilities are not approved to repay the existing credit facilities to take advantage of the new pricing [3].

The following questions have to be answered during this study:

1) To what extent could the banking finance at a normal interest rate effect on the financial performance of small business enterprises in Egypt?

2) What is the role of firm leverage and firm age in the impact on the financial performance of small business enterprises in Egypt?

3) What is the role of CBE to support small business compared to other developing countries?

4) Are there any problems faced by Small Businesses after obtaining bank financing?

5) What are small business enterprises in Egypt need to improve their financial performance?

The overall aim of this research is to measure the impact of banking finance at a normal interest rate on the financial performance of small business enterprises in Egypt and clarify the importance of banking finance for small business where small businesses suffer from many problems whether before obtaining funding or after funding.

There are three objectives aiming to achieve which are:

1) Measuring the impact of banking finance on the financial performance of 
small business enterprises in Egypt.

2) Measuring the role of Loans Volume and Firm Leverage on the financial performance.

3) Measuring the role of Loans Volume and Firm Age on the financial performance.

Two main research hypotheses are developed. Each hypothesis is tested once against the whole sample of Small Businesses and another time against Small Businesses with loans only. Hypotheses are stated as follows:

$\mathrm{H}_{1}$ : banking finance has a significant impact on small business Financial Performance

Sub $\mathrm{H}_{1}$ : banking finance has a significant impact of ROA.

Sub $\mathrm{H}_{1}$ : banking finance has a significant impact of ROE.

Sub $\mathrm{H}_{1}$ : banking finance has a significant impact of NPM.

H0: banking finance has an insignificant impact on small business Financial Performance

Sub H0: banking finance has an insignificant impact of ROA.

Sub H0: banking finance has an insignificant impact of ROE.

Sub H0: banking finance has an insignificant impact of NPM.

The research variables were defined and adopted according to the study of [4], [5] and [6] Research variables of this study are Banking Finance, representing the independent variable, Firm Leverage representing the control, and finally, Financial Performance Indicators (ROE, ROA and NPM), representing the dependent variable. Banking Finance is defined as the loans volume acquired by Small Businesses in Egypt in the year 2017. Firm Leverage is defined as the percentage of debt to asset presented in million EGP for the year 2017.

\section{Literature Review}

In this section, the researcher tries to make use of the literature review that is related with current study, explaining the impact of banking finance on financial performance of the Egyptian small business to figure out the gaps in these researches. This helps the researcher to develop the hypotheses relevant to the findings and recommendations and it provides details about the Egyptian experiences to support the small business enterprises as well as an overview of the Egyptian economy. Besides, an overview of the small business experiences in both developing countries. There are different points of views on the impact of banking finance on the financial performance of small businesses that it was an incentive for us to take care of this topic to fill these gaps. The majority of literature review showed that banking finance has a positive impact on the financial performance of small enterprises. The governments and lending institutions be supportive to the small enterprises and also advice small business on how to estimate their plan for viability to ensure that they make smart decisions when investing in projects. The small businesses be faced with difficulties when accessing finance from different sources. The majority of literature review was 
used sales growth, ROA, ROE, NPM and working capital as indicators of financial performance.

\subsection{The Importance of Banking Finance}

Working capital management (WCM) in small businesses is essential to sustaining the life of the business. A steady flow of cash is essential to maintain a business, and efficient working capital will maximize profitability, while poor WCM is one of the primary reasons for business failure. In this study, a sample of 200 Vietnamese Small Businesses was used to test the impact of WCM on the profitability in the period from 2010 to 2012. It was shown that that WCM is a significant area of financial management; the efficient WCM can significantly impact on the profitability and liquidity of the business. In this study, we find a significant negative relationship between gross operating income and the number of days of accounts receivable, accounts inventories and cash conversion cycle. These results are consistent with those found in previous studies in large firms, particularly in Small Businesses.

\subsection{The Impact of Banking Finance on Small Business}

[7] used secondary data that significant number of the small scale benefited from the microfinance institution credit facilities even though only few of them were suitable to secure the required amount needed. Interestingly the microfinance institution has grown phenomenally in the last 10 years. Majority of the small scale acknowledged positive contributions of microfinance institutions credit facilities towards promoting their market excellence and overall economic company competitive advantage like tax incentives and financial supports, the research recommend that the government should supply adequate infrastructural facilities such as electricity, good road network, and training institutions to help small scale in Nigeria.

Moreover, [8] investigated the small business experiences in Malaysia, using a secondary data that the key lessons that may benefit the Egyptian experience in the development of small business growth and access to finance can be summarized in the following points which are; top management commitment and setting up a committee engaged in policy and planning management and coordination, real employee participation, employee rewards and skills development. small business database will support bankers toward better planning to boost Small Businesses access to finance and introduction of new programs, the monitoring of existing programs being implemented in the areas of enhancing access to financing and developing financing products to support the small business different activities. Strengthening enabling business infrastructure, and boosting the capacity and capability of small business to able to produce favorable results in terms of productivity and performance across all sectors, modernization of equipment is necessary ingredients to enhance small business productivity and to accelerate the movement up the value chain.

The government should play a big role in learning small business practitioners 
on the incentives available to them and how to access them and delivering these incentives through many agencies. Small business should not totally rely on government institutes; they should try to find their own path of progress by relying on strategies. The government institutes have to invest more in marketing researches and innovation to support small business philosophy and its competitiveness have to establish credit guarantee schemes to support banks in increasing lending and decrease risks. To conclude Malaysia's success in achieving sustained growth can be summed up as "getting the basics right," through long-term planning and visionary leaders, development policies, good economic management, support private investment, develop human resource as well as develop good physical and institutional infrastructure [8].

\subsection{Firm Leverage, Firm Age and Financial Performance}

In general leverage has a negative impact on performance. However, it was also claimed that the leverage-performance relationship is significantly moderated by product diversity. In other words, leverage could be beneficial or detrimental to the financial performance of general insurance firms, contingent on the level of their product diversity. Firms with high leverage and high product diversity perform significantly better than firms with high leverage but low product diversity. Firms with low leverage are largely the smaller general insurers and these firms should focus on their respective niche product segments. Empirical evidence was provided that the leverage-performance relationship is a function of the product-mix strategy of the firm, and contributes to the existing literature by proving further insights on impact of leverage on firm performance and the role of product diversity in influencing the leverage-performance relationship in a highly regulated general insurance industry [9].

\section{Theoretical Background}

\subsection{Small Businesses Experiences in Egypt}

On 28/2/2017 a decision was issued by the Central Bank of Egypt stated as the new definition of Small business as follows: The medium companies, capital is from 5 million pounds to 15 million to industrial companies and from 3 million to 5 million to another company, work force is from 10 to 200 workers, sales are from 50 million pounds to 200 million pounds. In the small companies, capital is from 50 thousand pounds to 5 million to industrial companies and Less than 3 million to another company, work force is from 10 to 200 workers, and sales are from 1 million pounds to 50 million pounds. Allowing banks to finance small businesses whose sales range from 1 million to 10 million without obtaining audited financial statements and the lending rate for small businesses does not exceed $5 \%$ (decline simple rate).

The Social Fund Initiative

At the end of 2014, the Social Fund for Development (SFD) launched an initiative to support small businesses at an interest rate of $10 \%$ (decline simple rate) 
Table 1. Financial indicators for the Egyptian economy.

\begin{tabular}{ccc}
\hline List & $\mathbf{2 0 1 5 / 2 0 1 6}$ & $\mathbf{2 0 1 6 / 2 0 1 7}$ \\
\hline Real GDP growth rate & $4.3 \%$ & $4.2 \%$ \\
Average annual inflation rate & $13.97 \%$ & $23.3 \%$ \\
Budget deficit/GDP & $12.3 \%$ & $10.9 \%$ \\
$\begin{array}{c}\text { Average monthly exchange } \\
\text { rate per year (LE - USD) }\end{array}$ & $8.85 \mathrm{LE}$ & $14.7 \mathrm{LE}$ \\
Domestic debt/GDP & $96.7 \%$ & $91.1 \%$ \\
Unemployment rate & $12.5 \%$ & $11.9 \%$ \\
Net International Reserves & 17.5 billion dollars & 31.3 billion dollars \\
\hline
\end{tabular}

through more than 10 banks operating in Egypt Note that the mid corridor at this time was about $10.25 \%$ and the mid corridor rate at April 2018 about $18.25 \%$.

On 24/4/2017 a decree was issued by the Prime Minister of Egypt to establish the Small and Medium Enterprises Development Authority to replace the Social Fund for Development to include, training programs, financing programs, investment ideas and investment opportunities.

On May 2019 the Small and Medium Enterprises Development Authority launched a new initiative to support small businesses at an interest rate of 13\% (decline simple rate) through more than 10 banks operating in Egypt Note that the mid corridor at this time was about $16.25 \%$.

The Egyptian economy is one of the diversified economies in the Middle Eastinion-agriculture, tourism, manufacturing and services sectors. Due to recent structural reform, the Egyptian economy is achieving high growth rates-and an attractive investment climate has evolved thanks to positive developments in transportation, infrastructure, communication, skilled labor, energy, modern industrial cities, free zones, banking and stock markets. The following (Table 1) are the most important financial indicators for the Egyptian economy last two years.

\subsection{Banking Finance Experiences for Small Business in Some Developing Countries}

\section{Small business experiences in Malaysia}

Malaysia is an economy depending on natural resources and exploitation of the land, oil, gas, tin, timber, palm oil and rubber. However, after independence, industrialization led to the transformation of the Malaysian economy from resource and agriculture to industry [8].

Gross national savings is $38.2 \%$ of GNP, the GDP growth rate is about $5.8 \%$ and the unemployment rate is $3.5 \%$. Employment for about $56 \%$ of the total labor force and represent $99.2 \%$ of the total business establishments that provide as in 2009. the challenges faced by small business in Malaysia that the lack of a 
comprehensive framework in terms of policies towards small business development, inadequate data, too many agencies lacking effective coordination, limited access to finance and capital, difficulties in accessing loans, inability to survive in the mainstream of industrial development, underutilization of technical assistance, advisory services, lack of skilled and talented workers, and concentrated global competition from other producers. All of the mentioned challenges are almost similar to the situation of Egyptian small business. Malaysia is an economy depending on natural resources and exploitation of the land, oil, gas, tin, timber, palm oil and rubber. However, after independence, industrialization led to the transformation of the Malaysian economy from resource and agriculture to industry [8].

The objective was to develop capable Malaysian small business to become competitive in the global market. On the other hand, BNM offers financial advisory services. Banking institutions and other avenues of financing small business are specialized financial institutions, which are established by the government that aims at accelerating the growth of strategic sectors identified by the government.

In addition to Development Financial Institutions, there are other avenues of financing small business including small business Credit Bureau, venture capital, Agro-bank, leasing and factoring companies, all of which undertook a diverse range of financial initiatives To conclude Malaysia's success in achieving sustained growth can be summed up as "getting the basics right," through long-term planning and visionary leaders, development policies, good economic management, support private investment, develop human resource as well as develop good physical and institutional infrastructure [8].

\section{Small business experiences in India}

The small businesses have been the development driver of the Indian economy. The Indian economy, being one of the largest economies in the world as measured by the purchasing power parity (PPP) with a GDP growth rate about 7.2\% which makes it the third-biggest economy after China and the United States. The MSME sector contributes almost $40 \%$ to the entire output of India, $35 \%$ of the industrial exports and occupies $90 \%$ of the industry and the employment in the MSMEs sector in India increases to reach 732.24 lakh persons (73,200 mm) in 2010-2011 [10]. The challenges facing MSME sector in India; lack of finance, planning and marketing assistance, technology are main ones that hurdle SMEs from access to success. Reserve Bank of India is raising directions to all Banks to be followed in terms of allocating $40 \%$ of the finance at banks to SME annually. In case of not covering the allocated percentage, the reserve bank direct the remaining to finance one of the priority sectors like textiles and agriculture with interest rate never exceed $4 \%$.

\section{Research Methodology and Sampling}

The researcher has mentioned the Philosophy of the study which is Positivism Philosophy. Then, it was mentioned the followed approach which is deductive 
Approach. Also, the quantitative design was the design research in this study. The practitioner has collected historical secondary data collected from official periodicals. The unit of analysis was organizations where the data used is that of year 2017. All of this information will be mentioned in Table 2 as follows.

\section{Data Analysis and Findings}

In this chapter empirical study is illustrated for the purpose of test hypotheses. First, descriptive analysis was progressed to interpret the models' variables. Second, verification of the normality assumptions and third, testing regression assumptions will be presented with details in this chapter. Data analysis was conducted using correlation and regression.

\section{Descriptive Analysis}

Table 3 shows the measures of central tendency and dispersion of the research variables where the ROE was found to have the mean of 0.3803 , the ROA was found to have the mean of 0.2889 , the NPM was found to have the mean of 0.1450 , the Loans Volume was found to have the mean of 1.4891, and the Firm Leverage was found to have the mean of 0.3941, while Firm Age has a mean of 4.5000

Table 2. Research methodology summary.

\begin{tabular}{|c|c|}
\hline Philosophy & Positivism \\
\hline Approach & Deductive Approach \\
\hline Design & Quantitative Research Design \\
\hline Population & Small Enterprise in Egypt \\
\hline Sample Size & $\begin{array}{c}90 \text { small business firms in Egypt } \\
\text { in period from } 2013 \text { to } 2016 \\
\text { (2013 and } 2014 \text { without loan, } 2015 \text { and } 2016 \text { with a loan) }\end{array}$ \\
\hline Data collection & Historical Secondary Data collected from official periodicals \\
\hline Statistical Packages & SPSS \\
\hline Unit of analysis & Organizations unit of analysis where the data used is that of year 2017 \\
\hline Time Horizon & CNPMs Sectional \\
\hline
\end{tabular}

Table 3. Descriptive analysis for the research variables.

\begin{tabular}{ccccccc}
\hline & Range & Minimum & Maximum & Mean & Std. Deviation & Variance \\
\hline ROE & 1.24 & 0.01 & 1.25 & 0.3803 & 0.27134 & 0.074 \\
ROA & 0.98 & 0.01 & 0.99 & 0.2889 & 0.22456 & 0.050 \\
NPM & 0.40 & 0.00 & 0.40 & 0.1450 & 0.08124 & 0.007 \\
Log Loans Volume & 4.08 & 0.00 & 4.08 & 1.4891 & 1.53543 & 2.358 \\
Firm Leverage & 5.77 & 0.00 & 5.77 & 0.3941 & 0.59421 & 0.353 \\
Firm Age & 3.00 & 3.00 & 6.00 & 4.5000 & 1.11959 & 1.253 \\
\hline
\end{tabular}




\section{Normality Test}

Table 4 illustrates the formal test of normality assumption for the research variables, where it could be seen that the research variables are not normally distributed as the corresponding P-values are less than 0.05 .

The Relationship between Loans Volume and Financial Performance Indicators

Spearman correlation coefficients used to describe the relationships between the variables. Table 5 shows the correlation matrix for the relationship between Loans Volume and ROE. It was found that the relationship is insignificant, as the corresponding P-value is more than $0.05(=0.135)$ and the correlation coefficient is -0.079 .

Table 6 shows the correlation matrix for the relationship between Loans Volume and ROA. It was found that there is significant negative relationship, as the corresponding P-value is less than 0.05 and correlation coefficient is -0.212 .

Table 4. Formal testing of normality.

\begin{tabular}{ccccccc}
\hline & \multicolumn{2}{c}{ Kolmogorov-Smirnov $^{\mathrm{a}}$} & \multicolumn{3}{c}{ Shapiro-Wilk } \\
\cline { 2 - 7 } & Statistic & df & Sig. & Statistic & df & Sig. \\
\hline ROE & 0.118 & 90 & 0.000 & 0.922 & 90 & 0.000 \\
ROA & 0.119 & 90 & 0.000 & 0.899 & 90 & 0.000 \\
NPM & 0.066 & 90 & 0.001 & 0.972 & 90 & 0.000 \\
Loans Volume & 0.334 & 90 & 0.000 & 0.761 & 90 & 0.000 \\
Firm Leverage & 0.254 & 90 & 0.000 & 0.617 & 90 & 0.000 \\
Firm Age & 0.172 & 90 & 0.000 & 0.856 & 90 & 0.000 \\
\hline
\end{tabular}

Table 5. Correlation matrix between loans volume and ROE.

\begin{tabular}{lcccc}
\hline & & Loans Volume & ROE \\
\hline & Loans Volume & Correlation Coefficient & 1.000 & \\
Spearman's rho & & Sig. (2-tailed) & & \\
& \multirow{3}{*}{ ROE } & N & 90 & \\
& & Correlation Coefficient & -0.079 & 1.000 \\
& & Sig. (2-tailed) & 0.135 & \\
& & N & 90 & 360 \\
\hline
\end{tabular}

Table 6. Correlation matrix between loans volume and ROA.

\begin{tabular}{lcccc}
\hline & & Loans Volume & ROA \\
\hline & & Correlation Coefficient & 1.000 & \\
Loans Volume & Sig. (2-tailed) & & \\
Spearman's rho & & $\mathbf{N}$ & 90 & \\
& \multirow{2}{*}{ ROA } & Correlation Coefficient & $-0.212^{* *}$ & 1.000 \\
& & Sig. (2-tailed) & 0.000 & \\
& & $\mathbf{N}$ & 90 & 90 \\
\hline
\end{tabular}


Table 7 shows the correlation matrix for the relationship between Loans Volume and NPM. It was found that there is significant negative relationship, as the corresponding P-value is less than 0.05 and correlation coefficient is -0.110 .

The effect of Loans Volume, and Firm Leverage on Financial Performance Indicators

Table 8 shows the data for the regression model of the effect of Loans Volume and Firm Leverage on ROE. It could be noted that there is a significant negative effect of Loans Volume on ROE as the corresponding P-value is 0.005 with a coefficient of -0.028 , while, there is a significant negative impact of Firm Leverage on ROA as the corresponding $\mathrm{P}$-value is 0.025 with a coefficient of 0.057 . Also, coefficient of determination ( $R$ Square) is 0.027 which means that Independent Variables explain $2.7 \%$ of the variation in ROE.

Table 9 shows the data for the regression model of the effect of Loans Volume and Firm Leverage on ROA. It could be noted that there is a significant negative effect of Loans Volume and Firm Leverage on ROA as the corresponding $\mathrm{P}$-values for both variables are 0.001 with a coefficient of -0.026 , and -0.069 . Also, coefficient of determination ( $\mathrm{R}$ Square) is 0.086 which means that Independent Variables explain $8.6 \%$ of the variation in ROA.

Table 7. Correlation matrix between loans volume and NPM.

\begin{tabular}{lcccc}
\hline & & & Loans Volume & NPM \\
\hline & Loans Volume & Correlation Coefficient & 1.000 & \\
Spearman's rho & & Sig. (2-tailed) & & \\
& & $\mathrm{N}$ & 90 & 1.000 \\
& $\mathrm{NPM}$ & Correlation Coefficient & $-0.110^{*}$ & 90 \\
\hline
\end{tabular}

Table 8. Regression model of loans volume and firm leverage on ROE.

\begin{tabular}{ccccccc}
\hline \multirow{2}{*}{ Model } & \multicolumn{2}{c}{ Unstandardized Coefficients } & $\begin{array}{c}\text { Standardized } \\
\text { Coefficients }\end{array}$ & $\mathbf{t}$ & Sig. & R-square \\
\cline { 2 - 5 } & B & Std. Error & Beta & & & \\
\hline (Constant) & 0.399 & 0.020 & & 19.638 & 0.000 & 0.027 \\
Loans Volume & -0.028 & 0.010 & -0.158 & -2.851 & 0.005 & \\
Firm Leverage & 0.057 & 0.025 & 0.125 & 2.255 & 0.025 \\
\hline
\end{tabular}

a. Dependent Variable: ROE.

Table 9. Regression model of loans volume and firm leverage on ROA.

\begin{tabular}{ccccccc}
\hline \multirow{2}{*}{ Model } & \multicolumn{2}{c}{ Unstandardized Coefficients } & $\begin{array}{c}\text { Standardized } \\
\text { Coefficients }\end{array}$ & $\mathbf{t}$ & Sig. & R-square \\
\cline { 2 - 4 } & B & Std. Error & Beta & & & \\
\hline (Constant) & 0.354 & 0.016 & & 21.699 & 0.000 & 0.086 \\
Loans Volume & -0.026 & 0.008 & -0.175 & -3.253 & 0.001 & \\
Firm Leverage & -0.069 & 0.020 & -0.182 & -3.376 & 0.001 \\
\hline
\end{tabular}

a. Dependent Variable: ROA. 
Table 10 shows the data for the regression model of the effect of Loans Volume and Firm Leverage on NPM. It could be noted that there is an insignificant effect of Loans Volume on NPM as the corresponding P-value is 0.848 which is more than 0.05 , while, there is a significant negative impact of Firm Leverage on NPM as the corresponding P-value is 0.000 with a coefficient of -0.039 . Also, coefficient of determination (R Square) is 0.083 which means that Independent Variables explain $8.3 \%$ of the variation in NPM.

The effect of Loans Volume, and Firm Age on Financial Performance Indicators

Table 11 shows the data for the regression model of the effect of Loans Volume and Firm Age on ROE. It could be noted that there is an insignificant effect of Loans Volume and Firm Age on ROE as the corresponding P-values are more than 0.05 (0.413, and 0.786).

Table 12 shows the data for the regression model of the effect of Loans Volume and Firm Age on ROA. It could be noted that there is an insignificant effect of Loans Volume and Firm Age on ROA as the corresponding P-values are more than 0.05 (0.153, and 0.368).

Table 13 shows the data for the regression model of the effect of Loans Volume and Firm Age on NPM. It could be noted that there is an insignificant effect of Loans Volume and Firm Age on NPM as the corresponding P-values are more than 0.05 (0.192, and 0.716).

Analysis Conclusion

In this chapter, the descriptive, correlation and regression analysis were conducted to respond to the research hypotheses. Table 14 shows the results of the hypotheses based on the analysis.

Table 10. Regression model of loans volume and firm leverage on NPM.

\begin{tabular}{ccccccc}
\hline \multirow{2}{*}{ Model } & \multicolumn{2}{c}{ Unstandardized Coefficients } & $\begin{array}{c}\text { Standardized } \\
\text { Coefficients }\end{array}$ & $\mathbf{t}$ & Sig. & R-square \\
\cline { 2 - 5 } & $\mathbf{B}$ & Std. Error & Beta & & & \\
\cline { 1 - 5 } (Constant) & 0.161 & 0.006 & & 27.267 & 0.000 & 0.083 \\
Loans Volume & -0.001 & 0.003 & -0.010 & -.192 & 0.848 & \\
Firm Leverage & -0.039 & 0.007 & -0.285 & -5.282 & 0.000 \\
\hline
\end{tabular}

a. Dependent Variable: NPM.

Table 11. Regression model of loans volume and firm age on ROE.

\begin{tabular}{ccccccc}
\hline \multirow{2}{*}{ Model } & \multicolumn{2}{c}{ Unstandardized Coefficients } & $\begin{array}{c}\text { Standardized } \\
\text { Coefficients }\end{array}$ & $\mathrm{t}$ & Sig. & R-square \\
\cline { 2 - 5 } & B & Std. Error & Beta & & & \\
\cline { 2 - 5 } (Constant) & 0.436 & 0.096 & & 4.543 & 0.000 & 0.014 \\
Loans Volume & -0.016 & 0.019 & -0.089 & -0.819 & 0.413 & \\
Firm Age & -0.007 & 0.026 & -0.030 & -0.272 & 0.786 \\
\hline
\end{tabular}

a. Dependent Variable: ROE. 
Table 12. Regression model of loans volume and firm age on ROA.

\begin{tabular}{cccccccc}
\hline \multirow{2}{*}{ Model } & \multicolumn{2}{c}{ Unstandardized Coefficients } & $\begin{array}{c}\text { Standardized } \\
\text { Coefficients }\end{array}$ & $\mathbf{t}$ & Sig. & R-square \\
\cline { 2 - 5 } & B & Std. Error & Beta & & & \\
\hline (Constant) & 0.409 & 0.078 & & 5.270 & 0.000 & 0.059 \\
Loans Volume & -0.022 & 0.016 & -0.153 & -1.434 & 0.153 & \\
Firm Age & -0.019 & 0.021 & -0.096 & -0.902 & 0.368 & \\
\hline
\end{tabular}

a. Dependent Variable: ROA.

Table 13. Regression model of loans volume and firm age on NPM.

\begin{tabular}{cccccccc}
\hline \multirow{2}{*}{ Model } & \multicolumn{2}{c}{ Unstandardized Coefficients } & $\begin{array}{c}\text { Standardized } \\
\text { Coefficients }\end{array}$ & T & Sig. & R-square \\
\cline { 2 - 3 } & B & Std. Error & Beta & & & \\
\hline (Constant) & 0.143 & 0.029 & & 4.979 & 0.000 & \\
Loans Volume & -0.008 & 0.006 & -0.143 & -1.306 & 0.192 & 0.012 \\
Firm Age & 0.003 & 0.008 & 0.040 & 0.365 & 0.716 & \\
\hline
\end{tabular}

a. Dependent Variable: NPM.

Table 14. Summary of research hypotheses.

\begin{tabular}{|c|c|c|}
\hline Hypothesis & Description & Results \\
\hline $\mathrm{H}_{1}$ & $\begin{array}{l}\text { There is a significant negative role of } \\
\text { Loans Volume on Financial Performance Indicators }\end{array}$ & Fully Supported \\
\hline $\mathrm{H}_{2}$ & $\begin{array}{l}\text { There is a significant negative role of Loans Volume } \\
\text { and Firm Leverage on Financial Performance Indicators }\end{array}$ & Partially Supported \\
\hline $\mathrm{H}_{3}$ & $\begin{array}{l}\text { There is a significant negative role of Loans Volume } \\
\text { and Firm Age on Financial Performance Indicators }\end{array}$ & Not Supported \\
\hline
\end{tabular}

\section{Conclusions}

This study focuses on three main objectives, the first objective which is measuring the impact of banking finance on the financial performance of small business in Egypt is attained by formulating the first hypothesis and three sub hypotheses. The results showed that loan volume has a negative significant impact to financial performance of small business, firm leverage has a negative significant impact to financial performance of small business and firm age has insignificant impact to financial performance of small business.

There must be a financial management within each small company that is important to help to use bank financing in a timely manner and for the appropriate purpose. To achieve a positive effect of bank financing, the banking finance should help the assets turnover to increase net profit, provide the awareness of the use of short-term financing in short-term investments and the use of long-term funds in long-term investments and the use of financing for the purpose specified for it and not for any other purpose. Finally, the initiative of 
the Central Bank of Egypt to support small enterprises issued in January 2016 at a rate of $5 \%$ is very good compared to the market interest rates prevailing in the market and the MSME Development Agency initiatives issued at the end of 2014 with a $10 \%$ and 2019 with a $13 \%$ return rate. The State has to support small enterprises while offering tax and guarantee benefits to small enterprises. The Chambers of Commerce and Small Business Development Agency must provide training programs for small businesses related to capital management, human capital management and the extraction of export card and training programs related to customs' procedures and international trade agreements with the same degree of interest to senior firms and set database that includes the number of small projects in Egypt and the number of Beneficiaries of initiatives and the value of funds provided support.

\subsection{Contribution}

This research is considered useful for entrepreneurs and decision makers and anyone interested in small businesses. It helps understand the relationship between loan volume and financial performance as well as understanding the role of firm leverage as a moderator in this relationship. It also helps people who could benefit from the comparative study done between companies with loans and companies without loans in their field, in order to have more information to decide the best way to finance their business.

\subsection{Implications}

This study sheds the light on important points, which could be beneficial for policy makers in setting interest rate and facilitating the process of providing finance to small businesses to encourage economic development and boost entrepreneurship in Egypt.

\section{Conflicts of Interest}

The authors declare no conflicts of interest regarding the publication of this paper.

\section{References}

[1] Elsaid, A., Dawood, M., Seracino, R. and Bobko, C. (2011) Mechanical Properties of Kenaf Fiber Reinforced Concrete. Construction and Building Materials, 25, 1991-2001. https://doi.org/10.1016/j.conbuildmat.2010.11.052

[2] Selim, M.S., Shenashen, M.A., El-Safty, S.A., Higazy, S.A., Selim, M.M., Isago, H. and Elmarakbi, A. (2017) Recent Progress in Marine Foul-Release Polymeric Nanocomposite Coatings. Progress in Materials Science, 87, 1-32. https://doi.org/10.1016/j.pmatsci.2017.02.001

[3] Ndede-Amandi, A.A., Mbarika, V., Payton, F.C., Duplechain, S. and Mbarika, E. (2015) Women and Information Technology in Sub-Saharan Africa.

[4] Agus, A. (2011) Enhancing Production Performance and Customer Performance through Total Quality Management (TQM): Strategies for Competitive Advantage. 
Procedia-Social and Behavioral Sciences, 24, 1650-1662. https://doi.org/10.1016/j.sbspro.2011.09.019

[5] Petersen, M.A. and Schoeman, I. (2008) Modeling of Banking Profit via Return-on-Assets and Return-on-Equity. Proceedings of the World Congress on Engineering, Vol. 2, 1-6.

[6] Bae, Y.H. and Park, K. (2011) Targeted Drug Delivery to Tumors: Myths, Reality and Possibility. Journal of Controlled Release, 153, 198.

https://doi.org/10.1016/j.jconrel.2011.06.001

[7] Aremu, A.O., Amoo, S.O., Ndhlala, A.R., Finnie, J.F. and Van Staden, J. (2011) Antioxidant Activity, Acetylcholinesterase Inhibition, Iridoid Content and Mutagenic Evaluation of Leucosideasericea. Food and Chemical Toxicology, 49, 1122-1128. https://doi.org/10.1016/j.fct.2011.02.003

[8] Zakaria, H.M., Al Awad, N.A., Al Kreedes, A.S., Al-Mulhim, A.M.A., Al-Sharway, M.A., Hadi, M.A. and Al Sayyah, A.A. (2011) Recurrent Laryngeal Nerve Injury in Thyroid Surgery. Oman Medical Journal, 26, 34.

[9] Foong, S.Y. and Idris, R. (2012) Leverage, Product Diversity and Performance of General Insurers in Malaysia. The Journal of Risk Finance, 13, 347-361.

https://doi.org/10.1108/15265941211254462

[10] Zakaria, S.M., Sharif Zein, S.H., Othman, M.R., Yang, F. and Jansen, J.A. (2013) Nanophase Hydroxyapatite as a Biomaterial in Advanced Hard Tissue Engineering: A Review. Tissue Engineering Part B: Reviews, 19, 431-441.

https://doi.org/10.1089/ten.teb.2012.0624 